\title{
V. Nabokov's "Bend Sinister": A social message or an experiment with time?
}

\author{
Marina Grishakova \\ Dept. of Comparative Literature, University of Tartu, \\ Ülikooli 17, Tartu 50090, Estonia \\ e-mail: marina2@ut.ee
}

\begin{abstract}
The paper examines V. Nabokov's "strange" novel "Bend Sinister". The fictional space of the novel is regarded as a process of interaction of different languages or different versions of reality. The philosopher Krug's story unrolls in the imaginary totalitarian state whose ideology combines the elements of fascism, communism and the language of mass psychology. At this level the text is identical with a "social message". The protagonist has to choose between a "private autonomy" and a "bad solidarity". The paper offers the new facts and documents referring to the key symbols of the novel. The language of "reality" is deconstructed in the protagonist's idiosyncratical language, the language of his thoughts, recollections and dreams. Scientific metaphors are crucial in the deconstruction and help to reveal metafictional nature of the text. The analogies with painting, relativist physics, logical paradoxes (Russell's and Gödel's theories) permits to investigate the status of the fictional space, its development in time and the fiction of the Author.
\end{abstract}

Or is "outer" and "inner" an illusion too, so that a great mountain may be said to stand a thousand dreams high and hope and terror can be as easily charted as the capes and bays they helped to name?

(Nabokov 1974: 146)

Nabokov's "Bend Sinister" has been repeatedly evaluated as a strange or not quite successful text. There were few critical responses to it in 1947 when it was published and it is still surrounded by certain critical 
perplexity, although a number of scholars have paid close attention to it. D. Barton Johnson's thematic analysis (Johnson 1985: 185-223) and P. Tammi's narratological analysis in terms of the auctorial "incomplete control" over the text (Tammi 1985: 115-125) is especially revealing. Basing ourselves on these investigations, we will attempt to place the text into the context of culture and to examine it as a process of interaction of different languages.

The perplexity is probably caused by Nabokov's flat rejection of any general ideas and social comments applicable to "Bend Sinister" and by his delineation of the novel as an author's fantasy (Nabokov 1974: 6-7). Despite the author's will to prevent a "social intent" in the critical appraisal of the novel, the latter has been accepted as a parallel to other anti-totalitarian texts containing a "social message" ("Invitation to a Beheading", "Tyrants Destroyed", etc.). In the Introduction of 1963, Nabokov denied any didactic or allegorical goal, any "serious" idea, but admitted that "certain reflections in the glass directly caused by the idiotic and despicable regimes" can be distinguished in the book: "worlds of tyranny and torture, of Fascists and Bolshevists, of Philistine thinkers and jack-booted baboons" (Nabokov 1974: 6). The text might be understood more precisely as a system of contradictory elements both maintaining and undermining the "social message". The language of ideology is juxtaposed to the protagonist's idiosyncratical language. The philosopher Adam Krug refuses to accept the language of the social "conspiracy" since the people involved (classmates, colleagues, acquaintances) belong to his personal world: he is "re-writing" the totalitarian idiom and decomposing it into private human meanings. His philosophical method is defined as "creative destruction" of any closed, finite and therefore mythological system (Nabokov 1974: 145-146). The tension between the languages reaches its top point in the episode of protagonist's death while he attempts to re-turn the situation into the idiosyncratical recollection of a schoolgame or fight to subdue the dictator. The narration simultaneously opens at the level of the author-narrator whose presence permeates protagonist's idiosyncratical language as its "inner form".

\section{The social message}

According to the Introduction, "the greater part of the book was composed in the winter and spring of 1945-46" (Nabokov 1974: 5), but 
the work started already in 1942. Certain published and unpublished documents of the time should be appropriately related to the novel since they point at its key symbols and motives. On February 4, 1944, New York Browning Society invited Nabokov to give a talk and sent him a leaflet containing the schedule of meetings and description of lectures. The Society was founded to study and popularize Robert Browning's life and works, but it was engaged in other educational activities as well. As one can learn from the leaflet, German culture was a focus of the Society's interests in 1944. The description includes a report on Prof. Schneider's lecture on German philosophy accompanied by some observations on totalitarian elements in the German philosophical thought from Hegel to Nietzsche. The editor of the leaflet remarks:

... though it is a strange indictment to bring against philosophers, of all people, very humbly I would suggest that the German people are less to blame for misapplication of their ideas than are philosophers to blame for failing to see the logical and natural outcome of those ideas, when translated into action.

So philosophy is interpreted as a practical activity or spiritual leadership. The philosophical image of Adam Krug, a solitary, free "hunter" in the kingdom of thought, might have been consciously opposed to this "applied" philosophy. The leaflet ends with the following statement:

The German people must save themselves. The final picture cannot be that of a fully armed, powerful world force holding Germany in subjection - the final picture must be that of an aroused higher Germany, armed with the might of truth and right, standing, as does the higher nature of man in George Gray Barnard's famous statue, upon the vanquished form of her own cruel, bestial, depraved nature.

Miss Henrietta Green closed our December meeting with the singing of Schubert's "Gretchen am Spinnrode". In the last plaintive notes of that fresh, youthful voice, in the words "Mein hertz is sehr", one could fancy that one heard the pathetic cry of the submerged, tortured Germany, the gentle, kindly, friendly Germany, pleading for a chance to survive. That it be given a chance, is as important for the rest of the world as it is for Germany (Letters, folder 118).

The outlook for the future rebirth overshadows the ominous historical events, the actual historical tragedy of Germany related to similar ideas of national rebirth and might. Nabokov's fierce anti-German letter in reply where he turns to the literal, biological meaning of "na- 
ture" is an obvious reaction to the "metaphysical" phraseology and presumed political innocence of the leaflet:

I have lived in Germany for 17 years and am quite sure Gretchen has been thoroughly consoled by the secondhand, somewhat bloodstained, but still quite wearable frocks that her soldier friend sent her from the Polish ghettos. No, I am afraid we shall never see the Barnard statue in a German impersonation. It is useless looking at a hyena and hoping that one day domestication or a benevolent gene will turn the creature into a great soft purring tortoiseshell cat. Gelding and Mendelism, alas, have their limits. Let us chloroform it — and forget. (Nabokov 1991: 47-48).

The letter is directed against a straightforward interpretation of the European situation through democratic ideas. George Gray Barnard's name is not casual: the artist was famous for his sculptural illustrations of the American democracy ("Struggle of the Two Natures in Man", 31 allegorical figures "Broken Laws" and "Laws We Keep", the statue of Lincoln). "A tortoiseshell cat" as a symbol of a "domestic" and "gentle" Germany appears in the episode of an emergency session at University President Azureus' place in "Bend Sinister" (Nabokov 1974: 43-44). It is probably worth to note that in the Soviet tradition the sentimental dictator and a cat are the usual pair in children's literature on Lenin. Nabokov made use also of the "Gretchen" metaphor. In the novel, the Bachofen sisters, outwardly erotic and submissive, actually cruel, practical and deceitful represent Germany-Gretchen. Mariette Bachofen exposed to the violence of soldiers embodies "the gentle, kindly, friendly Germany, pleading for a chance to survive". The theme of Nazism as a violence inflicted "on the gentle, cultured German people" (Boyd 1992: 86) emerges also in "Double Talk" and "Pnin". The following passage evokes the style of the leaflet and discredits the apprehension of culture as an autonomous, safe and "innocent" entity:

...she was selected to die and was cremated only a few days after her arrival in Buchenwald, in the beautifully wooded Grosser Ettersberg, as the region is resoundingly called. It is an hour's stroll from Weimar, where walked Goethe, Herder, Schiller, Wieland, the inimitable Kotzebue and others, "Aber warum - but why - " Dr Hagen, the gentlest of souls alive, would wail, "why had one to put that horrid camp so near!" for indeed, it was near - only five miles from the cultural heart of Germany - "that nation of the universities", as the President of Waindell College, renowned for his use of the mot juste, had so elegantly phrased it when reviewing the European situation in a recent Commencement speech, along with the compliment he paid another torture house, "Russia - the country of Tolstoy, Stanislavski, Raskolnikov, and other great and good men" (Nabokov 1997: 113). 


\section{Marina Grishakova}

Nabokov notes approvingly the following idea of the leaflet: "In Goethe, it is true, were found what seemed to be fundamental flaws in character, flaws which seem also to be inherent in the type of German now in power" (Letters, folder 118). "Bend Sinister" is permeated with polemical allusions and references to Goethe. For example, a paraphrasis of the famous Goethe's statement: "I am born to lead as naturally as a bird flies" (Nabokov 1974: 27). The story of the production of "Hamlet" in the State Theatre where "Osric and Fortinbras have acquired a tremendous ascendancy over the rest of the cast" (Nabokov 1974: 96) contains a reference to the staging in "Wilhelm Meister's Apprenticeship": the actress and the producer, "like Goethe, imagine Ophelia in the guise of a canned peach: 'her whole being floats in sweet ripe passion,' says Johann Wolfgang, Ger. poet, nov., dram. \& phil. Oh, horrible" (Nabokov 1974: 104). Therefore the interpretation of "Hamlet" as "a play founded upon young Fortinbras' attempt to recover the lands lost by his father" with clear racist and antiSemitic connotations (Nabokov 1974: 97) presents evidently reductio ad absurdum of Wilhelm Meister's version of Shakespeare where an essential part of action is transferred to Norway and Hamlet is a blond and blue-eyed Nordic hero.

All these allusions and explicit statements by Nabokov are, of course, clear "social comments". But, in Nabokov's own words, "Bend Sinister" is first of all a story of the protagonist and his creator. Nabokov's letter to his fellow-émigré Zenzinov (March 17, 1945) indicates a contradiction underlying the plot of "Bend Sinister": it is, in R. Rorty's terms, the theoretical incompatibility of "private autonomy" and "solidarity" (Rorty 1989). Nabokov's indignant remark was caused by V. Maklakov's, the official representative's of the Russian émigrés in France visit to the Soviet embassy:

I can understand denying one's principles in one exceptional case: if they told me that those closest to me would be tortured [to death - M. G.] or spared according to my reply, I would immediately consent to anything, ideological treachery [betrayal of principles - M. G.] or foul deeds and would even apply myself lovingly to the parting on Stalin's backside (Boyd 1992: 84).

As it seems, the idea of the letter is reflected in the significant symbols of "mug" (Krug, not a perfect "circle", but a "mug" in German or "kruzhka" in Russian: the latter might be interpreted as a diminutive of "krug" in Nabokov's playful language) and "handle" (a vulnerable point, a lever to handle, to manipulate a man) in "Bend Sinister". It is 
a polemical idea: personal attachments and fears are stronger than social rules. What is called a "historical necessity" consists of personal feelings and inclinations. One should not be misled by "common goals". The "social" and "personal" meanings are often polemically juxtaposed in Nabokovian metaphors. For example, the episode of Krug's death that could be regarded as a heroic suffering in another, non-Nabokovian system of thinking, turns out to be a schoolboys' game or fight. At the same time it might reflect a real mutilation of a Tenishev school student during a football game or Nabokov's own football trauma in Berlin in 1932 (Leving 1999: 131). The moment of death is especially significant as a realization of the major Nabokovian theme of crossing a border (Levin 1998): a process of passage resists any "general" interpretations and the very idea of passage is usually eclipsed by sharp sensory, especially visual impressions. For example, Nabokov's poem "The Execution" (1928) equalizes shooting (execution) with a photographic flash. The wordplay is apparently based upon the two meanings of the English verb "shoot": "to hit or kill with firearms" and "to take shots/ pictures" (see Emerson 1912, Barthes 1981 on photography as death; cf. also the simultaneity of the photographic flash with death in "Transparent Things"). In "Bend Sinister" the writer resorts to the verb's third meaning: "to send a ball (in sports)".

Certain letters of 1944 support the interpretation. It is clear, for example, from the letters of Dr. Leon Dinkin (Letters, folder 42) that the Nabokovs consulted him about their son's health in 1944 (a stomachache of uncertain origin). The "exploratory laparotomy" (incision into the abdomen) was proposed by doctors, but Dinkin was resolutely against it and offered to bring Dmitrii to New York for further observation under his control. Dmitrii might even enter some New York school: "It may sound monstrous to you, but it is still better than gut [eviscerate] him, excuse me for such a word. I am definitely against the operation" [the translation is mine. - M. G.]. It is noteworthy that Nabokov sent a copy of "Bend Sinister" to Dinkin. The doctor thanks him for it in his letter of August 20, 1947, and reports: "I read it through one evening and half of the night and did not sleep the rest of the night. It is really sinister". Evidently "horrors" of the radical Western medicine may have no less impact on an individual sensibility than the violence of totalitarian rule which uses "the diabolical method [...] of tying a rebel to his wretched country by his own twisted heartstrings" (Nabokov 1974: 7). 
A "release game", one of the most unpleasant episodes of "Bend Sinister", combines the aforementioned meanings (the cruelty of schoolgames, medical horrors) with the rudeness and falsity of imaginary psychoanalytical manipulations aimed at the release of the "collective unconscious". "Personal" (autobiographical) and "social" (historical, cultural, philosophical) subtexts are systematically brought together in Nabokov's work into singular polygenetic textual constructions (see Tammi 1999 : 34-64 on Nabokov's polygenetism).

In April of 1946, Nabokov received the letter of M. Kaminka. From this and following letters (Letters, folder 83) he found out the destiny of his Berlin friends and acquaintances. Mikhail Kaminka was a former Tenishev student like Nabokov. His father, August Kaminka, a prominent Russian lawyer, scholar and political figure, fled to Berlin from the Bolshevist regime. M. Kaminka describes the death of his father in a German camp in Latvia or Lithuania: it is evident from the letter that he had stayed in the camp voluntarily, despite the permission of the German authorities to go free obtained by his wife. Mikhail expresses the hope that his father could have used the poison he had prepared in case of Bolshevik arrest. But the Bolsheviks turned out to be tolerant to both A. Kaminka and Nikolai Vasilievich (Yakovlev?). These men took refuge in the Baltics after they left Berlin and soon found themselves between the two dangerous regimes: the condition probably symbolized by Adam Krug's "intermediary" position on the bridge in Nabokov's novel. Their fate was different. M. Kaminka describes also his mother's painful diseases after her husband's death.

Another man very significant for Nabokov and mentioned in M. Kaminka's letter was the philosopher Grigorii Landau. On my opinion, he might have been one of the possible prototypes for Adam Krug (a philosopher who started from the philosophy of history and ended as an aphorist - cf. Landau's "The Twilight of Europe" and "Epigraphs"). The Bolsheviks offered him a return to Russia and collaboration. M. Kaminka assumes that he might have been then subjected to "Gletkin" tortures (see A. Koestler's "Darkness at Noon") or, to the contrary, might have been one of the very few Jews who survived in Latvia. Now it is known that Landau died in the Soviet camp in Siberia (Ravdin 1994).

"The Twilight of Europe" examines the inner tensions of the European space between the two world wars and to a certain degree anticipates the social criticism by European and American intellectuals after World War II. The book brings us closer to the reasons of Nabokov's 
distrust of democratic slogans which sometimes disguise totalitarianism. According to Landau, in World War I the allies destroyed Germany in the name of an ideal, unhistorical aim of "absolute peace". They proclaimed this sacred idea, and not their own profit or benefit, to be the genuine goal of the war. It was not a war against Germany but the War against premises of any future war and injustice nesting in Germany. Pacifism itself becomes a tool of the war to compel all dreamers and compassionate people not indifferent to the suffering of other human beings to take the side of enemies of Germany. We would call such an ideological challenge the "abuse of solidarity" following R. Rorty's understanding of "solidarity" as a capacity to sense cruelty and other people's humiliation (Rorty 1989).

Landau supposes that the easy birth and spreading of "absolute" ideas are maintained by the common history of modern Europe. The common space of European culture has produced extremely close and intense communications and the feeling of accessibility of any goals. Idealistic maximalism is inherent in the proud and conceited European culture. In creative work, this pride is justified: being ineffective without competence and beneficial in "experts" or "professionals", it becomes dangerous while descending from "heroes" and "creators" to the ignorant "public". The pride spreads with consummate ease in the social and political sphere where everyone participates in action and shares self-confidence with others. Mass culture is governed by approximateness: it lacks the exact notions and weighted promises of experts. It is clear, says Landau, where this slope leads us when a crowd of professional leaders of society (politicians, journalists, preachers, ignorant writers and teachers) steps on it: shepherds themselves belong to the herd. The common ground of contemporary communications produces the effect of "flatness": the society overgrows old systems of thought developed by humankind by means of hard work and inherits only naivety instead of spontaneity and rationalism instead of wisdom. The masses imagine that it is easy to arrange the world according to their reasonable wishes.

According to Landau, Germany had accumulated a considerable creative potential by the early $20^{\text {th }}$ century. The defeat of Germany in the First World War was the defeat of Europe. The triumph of masses started. It seems that Landau's diagnosis has had an impact on Nabokov's ideas of "Ekwilism", "the Party of an Average Man" and all symptoms of oblivion of history and mental degeneration in the Padukgrad inhabitants. A. Dolinin wrote that Landau's pathos of 
European energies and creativity had probably influenced the conception of "Glory" (Dolinin 1999, 206). In "Bend Sinister" other, anxious thoughts about European history break out. They are close to Landau's reflections on the unstable balance of democracy and totalitarianism.

Landau's thesis on the easy accessibility of an "extreme" idea could also attract Nabokov's attention: the real growth of knowledge consists in the accumulation of axiomata media, intermediate steps. The irrealism of "ideal aims" destroys the living reality. Reality descends to an inferior level or falls into an abyss. The idea of the destructiveness of "idealistic maximalism" is also prominent in "Lolita", where it assumes a form of the Romantic-decadent solipsistic quest for the lost or imaginary beloved and entails Humbert's obsessive actions.

Landau's book contains the polemics with Spengler, his notions of organic growth and decline of cultures (cf. polemics with Spengler in "Glory" and "The Gift" - A. Dolinin 1999, 204-206). Landau asserts that the highest functions of culture contradict its "organic". The superdevelopment or supertension of an isolated function in an organism contradicts its organic wholeness and causes its destruction. The existence of the highest functions of culture (such as, for example, philosophical thinking) is possible only if there are forces and materials free from organic development. Contradiction is an essential form of life and dissatisfaction is a basic law of it. The more developed a culture, the sharper this tragic contradiction. Nabokov's permanent opposition to the systems which pretend, like Marxism or psychoanalysis, to be able to resolve contradictions and to fulfill wishes, is well-known. A contradiction underlies "Bend Sinister": Adam Krug's heavy body belongs to the restricted physical reality, his consciousness strives for infinite freedom. The contradiction is not an expression of the traditional RomanticSymbolist dualism of nature (of the "inward" and "outward" reality): it is inscribed into scientific metaphors.

\section{The philosophy of time: Nabokov and Dunne}

In the unpublished chapter of "Conclusive Evidence" Nabokov, who refers to himself in the third person, mentions "Mr. Nabokov's method of referring to himself in the third person as "Sirin":

One is reminded of those problems of "objectivity" that the philosophy of science brings up. An observer makes a detailed picture of the whole uni- 
verse, but when he has finished he realizes that it still lacks something: his own self. So he puts himself in it too. But again a "self" remains outside and so forth, in an endless sequence of projections, like those advertisements that depict a girl holding a picture of herself holding a picture of herself holding a picture that only coarse printing prevents one's eye from making out (Nabokov 1999: 128; the chapter was written in 1950)

The outlined problem arises together with the discovery by relativist physics of the impossibility to describe the world without including a human "observer". Some relativist allusions in Nabokov's work have been pointed out already (Grishakova 1999; Grossmith 1991). The Einsteinian system is based on the observation of two (or more) observers, but ignores the existence of the "last" observer: there must be the third observer (the fourth, the fifth, etc.) observing the previous observers. That was the point of the critique directed against the theory of relativity by John William Dunne, a British philosopher of science. Modern physics actually refers to the Pascalean philosophy of the "Hidden God" and the "truth" as a matter of point of view or perspective (Grishakova 1999). Blaise Pascal "aura été le premier à jouer systématiquement du paradigme à des fins philosophiques et/ou apologétiques, et à en jouer en pleine conscience de ses implications théoriques" (Damish 1987: 63).

The Pascalean subtext and the fiction of the "invisible observer" as the Author of the World vs. the author of the text appears already in Nabokov's Russian novels. Vera Nabokov's letter of June 15, 1961, on behalf of her husband, to the American publisher of "Lolita" Walter Minton contains a significant indication: "DAR consists of five chapters, four of these are written by the author (as invisible observer), the fifth (No. 4 in the sequence) purports to be the work of the main protagonist" (Letters to G. P. Putnam's sons). Another important author's remark accompanies M. Scammell's typescript translation of "The Gift" (the end of chapter 4, Busch's speech on the atomuniverse): "Busch in his grotesque way expresses a deep and important theory, and its meaning should be brought out clearly, despite the ranting" (Dar: 249). Busch's ranting and grotesque speech refers to Fragment 72 (Brunschwicg's numeration) of Pascal's "Thoughts" which develops an idea of the immensity of the universe: "The whole visible world is only an imperceptible atom in the ample bosom of nature. No idea approaches it. We may enlarge our conceptions beyond all imaginable space; we only produce atoms in comparison with the reality of things. It is an infinite sphere, the centre of which is eve- 
rywhere, the circumference nowhere". Each smallest part of nature is an "abridged atom" of its immensity: there is "an infinity of universes, each of which has its firmament, its planets, its earth, in the same proportion as in the visible world". Man is "a mean between nothing and everything":

What will we do then, but perceive the appearance of the middle of things, in an eternal despair of knowing either their beginning or their end. All things proceed from the Nothing, and are borne towards the Infinite. Who will follow these marvelous processes? The Author of these wonders understands them. None other can do so (Pascal: 1958: 16-18).

Pascalean allusions are related to Nabokov's implicit polemics with the theory of relativity. The distinction between the "inward" and "outward" space is illusory: it is just a habit of our thinking since the world contains immeasurable worlds enclosed one within the other. Human knowledge is inevitably partial, only the Author of the Universe can play the role of the privileged "objective" observer. The polemics is taken up again in Ada's letter on "physics fiction" in "Ada": "Elaborating anew, in irrational fabrications, all that Cyraniana and 'physics fiction' would have been not only a bore but an absurdity, for nobody knew how far Terra, or other innumerable planets with cottages and cows, might be situated in outer or inner space: 'inner', because why not assume their microcosmic presence in the golden globules ascending quick-quick in this flute of Moët or in the corpuscles of my, Van Veen's - (or my, Ada Veen's) — bloodstream" (Nabokov 1970: 258-259).

J. W. Dunne proposed the theory of serialism to resolve the problem of the "last" observer. In Chapter 2 of "The Serial Universe" he uses the following example to illustrate his ideas. A painter who escaped from the lunatic asylum began to draw a picture of the universe. He painted the landscape as he saw it, but noticed that something was missing and soon understood that he himself was missing as a part of the universe. "With the remorseless logic of the lunatic" (Dunne 1934: 30 ) the insane artist proceeds to expand his picture, portraying himself as a part of the universe, then adding again himself who is aware of his own existence, etc. etc. - the multiple picture with an increasing number of artists of increasing capacity.

The artist is trying to describe in his picture a creature equipped with all the knowledge which he himself possesses, symbolizing that knowledge by the picture which the pictured creature would draw. And it becomes abundantly evident that the knowledge thus pictured must always be less than the 
knowledge employed in making the picture. In other words, the mind which any human science can describe can never be an adequate representation of the mind which can make that science (Dunne 1934: 32).

As Dunne infers, one can systematically (rationally) treat the condition that we are self-conscious creatures aware of something other than ourselves, only exhibiting it in the form of an infinite regress and viewing all experience in terms of time: "The notion of absolute time is a pure regress. Its employment results in exhibiting us as selfconscious observers" (Dunne 1934: 34). In the above-cited passage from the unpublished chapter of "Conclusive Evidence" Nabokov apparently borrowed the argument from Dunne. But was not the parable of the insane artist the conceptual kernel of "Pale Fire": mad Kinbote imposing himself on Shade's life and poetry by means of his obsessive commentary, but also the author who endeavours to express himself through a series of imaginary literary substitutes? A similar parallel between the "self-conscious" novel technique and the "selfconscious" landscape painting appears already in "The Real Life of Sebastian Knight" (1941):

...The Prizmatic Bezel can be thoroughly enjoyed once it is understood that the heroes of the book are what can be loosely called "methods of composition". It is as if a painter said: look, here I'm going to show you not the painting of a landscape, but the painting of different ways of painting a certain landscape, and I trust their harmonious fusion will disclose the landscape as I intend you to see it (Nabokov 1995: 79).

In "An Experiment with Time" Dunne emphasizes that the things which belong to the core of human experience (sensations of colour, sound, etc.) are not explainable in the frame of objectivist science: "Physics is, thus, a science which has been expressly designed to study, not the universe, but the things which would supposedly remain in that universe if we were to abstract there from every effect of a purely sensory character" (Dunne 1973: 18). The scientific procedure consists in pushing the observer as far back as possible,

reducing him to the level of a helpless onlooker with no more capacity for interference than has a member of a cinema audience the ability to alter the course of the story developing before him on the screen. $<\ldots>$ It is a permanent obstacle in the path of our search for external reality that we can never entirely get rid of this individual. Picture the universe how we may, the picture remains of our making (Dunne 1973: 21). 
According to J. W. Dunne, this obstacle cannot be removed, but can be acknowledged and used in experimental knowledge based upon the notions of time and the moving observer. It is not Time, but the observer who moves. He observes, i.e. his field of presentation (a brief span of attention, the "now") moves within Time. The Time substratum exists constantly: the past, the present and the future are simultaneous. But the observation itself (the movement within the Time dimension) takes time. It is another time, the time of the higher order: it transpierces the primary time in its past, present and future. So the distinction is drawn between events observed and observational events. Time is serial and there is the serial observer. The first observer exists in the usual three-dimensional space where the fourth dimension is time. The primary time is the fourth spatial dimension for the four-dimensional second observer whose time is the fifth dimension, etc., etc. The field of the primary observer is absent in dreams, therefore observation is wandering hither and thither (in the past and future) by flashes. That is why the "anticipation" of the future events happens in dreams. A mental barrier between the past and the future exists only when we are awake: "In reality, the associational network stretched, not merely this way and that way in Space, but also backwards and forwards in Time" (Dunne, 60). On waking, the usual three-dimensional interpretations are applied to the dream logic. The dream results from the process of observation of the higher-order observer whom man has hypostatized into the figure of "animus", the mysterious soul that is actually equal to his own mental states: "Although the "higher-order observer" is nothing more magnificent or more transcendental than one's own highly ignorant self, he is beginning to look perilously like a full-fledged "animus"" (Dunne 1973: 167). One may suppose that death is a phenomenon of threedimensional continuum, a break similar to sleeping and other alternative states of consciousness.

Any world which is described from observation must be, as thus described, relative to the describing observer. It must, therefore, fall short of accordance with reality in so far as it cannot be thought of, by anyone who accepts the said observer's description, as capable of containing that observer. Consequently, you, the ultimate, observing you, are always outside any world of which you can make a coherent mental picture. If you postulate the existence of other observers making different descriptions, then it turns out that you and these observers must together form a composite observer who is not includible in the world as thus conjointly de- 
scribed. You, as part of that composite observer, retain your individuality $[\ldots]$

The picture you draw shows the real world in its relation to yourself - shows, that is to say, how that world is capable of affecting you. If drawn as the composite effort of many observers, it shows how the physical world is capable of affecting Mind in general. The most important fact which emerges is that you prove to be the immortal part of an immortal composite observer... (Dunne 1973: 190).

Nabokov tried Dunne's method examining his own dreams. As it seems, the idea of the "serial observer" emerges also in his literary texts: the writer has transformed Dunne's philosophical metaphors into a literary technique. Nabokov used the edition of 1945 of "The Serial Universe" for his manuscript "Notes for Texture of Time" (1957-1961) and the third edition of "An Experiment with Time" (1934, first published in 1927) for his own experiments.

The device of the "serial observer" is at its most obvious in "Bend Sinister", "Pale Fire" and "Transparent Things". "Bend Sinister", permeated with critical references to the relativity (Grishakova 1999), may be understood as a composite dream: a preliminary title "A Person from Porlock" refers to Coleridge's famous vision. The author/narrator is "dreaming" of Krug's life. Both dream and narration are the forms of absence in three-dimensional space accompanied by the "transparence" of the latter acquired due to the higher level of observation and by the spatialization of the lower-order time. Thus the metaphor of "observation" is metafictional: it signifies a process of writing (cf. Iser 1993: 16: an act of fictionalizing turns elements of the given world into objects for observation; the fictive "implies creating a position from which the represented world becomes observable"). The time of the observation intersects the space-time where Krug lives, acts and dies. Krug is also dreaming of himself. It is a multilevel dream (cf. "I want to wake up. Where is he? I shall die if I do not wake up": Nabokov 1974: 186). His dreams are pierced by the presence of a "mysterious intruder" or "genius" (Dunne's animus), the "higher-order observer" whose associational network stretches backwards and forwards in time (Dunne 1973: 60) and who is apparently common to both the hero and author. In the state of madness, which is another form of absence in three-dimensionality, Krug "suddenly perceives the simple reality of things and knows but cannot express in the words of his world that he and his son and wife and everybody else are merely my whims and megrims" (Nabokov 1974: 7). The border between the two worlds has became transparent: "Krug's conscious- 
ness has at least partly merged with that of his creator, for he is now aware of events in both worlds" and hears "the cautious crackling of a page" thrown into the author's wastebasket (Johnson 1985: 192). In the end, an author's sudden breaking through of the "imaginary" space of the text is introduced. It is a new level of serial time where Krug's schoolgame, death and return to his higher "self" are simultaneous, but not the last level since the "real" Author of the text stands behind the author/narrator. As it is known from Nabokov's letter to Edmund Wilson (cit. in Johnson 1985: 193), his initial intention was the "confrontation" of the protagonist and the author, which would apparently mean the inclusion of auctorial "unlimited freedom" into the finite mode of the "real" being.

The dream is nevertheless an unclear, imperfect form of observation, a "bad staging" with numerous unnecessary details. The similar idea is conveyed in "Transparent Things": "Dream-man is an idiot not wholly devoid of animal cunning" (Nabokov 1972, 60). Dunne also remarks that "the dreaming mind is a master-hand at tacking false interpretations on to everything it perceives" (Dunne 1973, 67).

As it often happens in Nabokov, "Transparent Things" seems to be a twin-text for "Bend Sinister" and "Pale Fire", the text parodying the same device of the serial observer. The "dead author", the floating (wandering) identity of characters (a "person", a "pilgrim"; "a person dancing in a variety of forms around his own self" — Nabokov 1972: 92), the dreamlike reality, anticipations — all these features have been already noticed.

Nabokov creates the illusion of an exact chronology based mainly on number 8 , the reversed symbol of infinity. Person comes to Switzerland at the age of 22 (his father's death follows); during the next visit he is 32 , he meets and marries Armande; during the last, fatal visit he is 40 and exactly 8 years have passed (it was August when he met Armande 8 years ago, he is apparently back again in August: "there was to be, or would have been (the folds of tenses are badly disarranged in regard to the building under examination) quite a nice little stream of Germans in the second, and cheaper, half of $\mathrm{Au}$ gust" - Nabokov 1972: 100). 8 months (from August to March) spent with Armande are mysteriously absent in this chronology: the first appointment, honeymoon in Stresa, Person's third visit to Europe, the hypothetical murder - all happened 8 years ago. One may suppose that Armande might have been only an imaginary point in multiple networks of time. 
The very notion of "transparence" has the special, Dunnian meaning in "Transparent Things", and the last letter of R. contains an ironical hint at both the "composite observer", whose shape he is assuming before the death, and its creator Dunne:

I believed that treasured memories in a dying man's mind dwindled to rainbow wisps; but now I feel just the contrary: my most trivial sentiments and those of all men have acquired gigantic proportions. The entire solar system is but a reflection in the crystal of my (or your) wrist watch. The more I shrivel the bigger I grow. I suppose this is an uncommon phenomenon. Total rejection of all religions ever dreamt up by man and total composure in the face of total death! If I could explain this triple totality in one big book, that book would become no doubt a new bible and its author the founder of a new creed. Fortunately for my self-esteem that book will not be written - not merely because a dying man cannot write books but because that particular one would never express in one flash what can only be understood immediately (Nabokov 1972: 84).

There is another important point which Nabokov could have made use of turning Dunne's philosophical construction into a literary technique: it is his favourite theme and device of pattern. Travelling in Time inevitably meets irregularities which are the movements of objects in the three-dimensional world. But a considerable amount of these irregularities might present a pattern for the observer. Thus, the "pattern" results from the interaction of the individual observer's attention and movement in time: it acquires its meaning only through recurrence and not through the unfolding a priori sense.

The early 20th century literature and philosophy had discovered the individual perceptual time. Nabokov's intention was probably the introduction of several individual time-orders, their "objective" exposition as different perceptual fields within the single, "subjective" field of perception, i.e. the qualitative alteration as well as expansion of the latter. The device of the "serial" observer reveals a certain affinity between the meta-fictional and meta-physical problems: the status of the textual world, its development in time, the fiction of the creator. It apparently had a personal significance for Nabokov who experienced multiple shifts in space and time before he escaped the awful "dream" of pre-war Europe.

The theme of "Hamlet" provides probably the most important key to the novel. Both the Shakespearean and Nabokovian hero need to "re-play" or "re-write" the reality in their own idiosyncratical language to handle it. Appealing again to Rorty's analysis, we agree that 
Nabokov's ability to sense cruelty ("solidarity") was very high and his faith in a possibility to rationalize social life and make it free of cruelty was very weak. But the conflict of "Tyrants Destroyed" and "Bend Sinister" does not rest in the incompatibility of "private autonomy" and "solidarity": it is rather a matter of choice between a "private autonomy" and a "bad solidarity". The latter means an abuse of the human capacity for "solidarity" (i.e. the capacity to share other people's feelings) based on some false idea assuming a form of common emotion or conviction. As it becomes evident in the novel, there is no principal theoretical difference between the psychology of advertising and the psychology of totalitarianism. Both use the vocabulary of "solidarity" and different modes of hypnotic suggestion or "collective mysticism" to achieve their goals. The choice is difficult since the protagonist (in both Shakespeare and Nabokov) is linked to the "bad" solidarity by personal ties and memories forming a part of his private idiosyncrasy and making him especially vulnerable. He can only view the reality through the language of his "private autonomy" since the language of "solidarity" is misused and compromised. It is not his "solipsism" or indifference to the outward world, but the historical paradigm, which does not leave him any choice.

The impossibility of choice complicates also the metafictional task of "creating a position from which the represented world becomes observable" (Iser 1993: 16). The text develops as a "serial dream" of multiple observers or the different independent modes of auctorial vision. On the one side, the author is an anonymous space of the intersection of different languages. On the other side, the narrative "is evolving by degrees towards an ever greater individuation" of the author-narrator whose personal presence might be traced throughout the whole text, but whose control over the fictional worlds is "only a comparative matter" (Tammi 1985: 115). It seems that the text construction is determined not so much by the optimistic evolvement of the Infinite Consciousness of Gnosticism, but rather by the paradoxality of all attempts to imagine or to depict infinity. The final coincidence of finity and infinity in the author-persona reminds of those riddles which agitated European science in the 1920-50s: the "last" observer in relativist physics, logical paradoxes, Gödel incompleteness theorem in response to Russell's hierarchy of restrictive "types". Escher's strange pictures of the 1930-50s (Fig. 1) presented the visual analogies for logical paradoxes: 


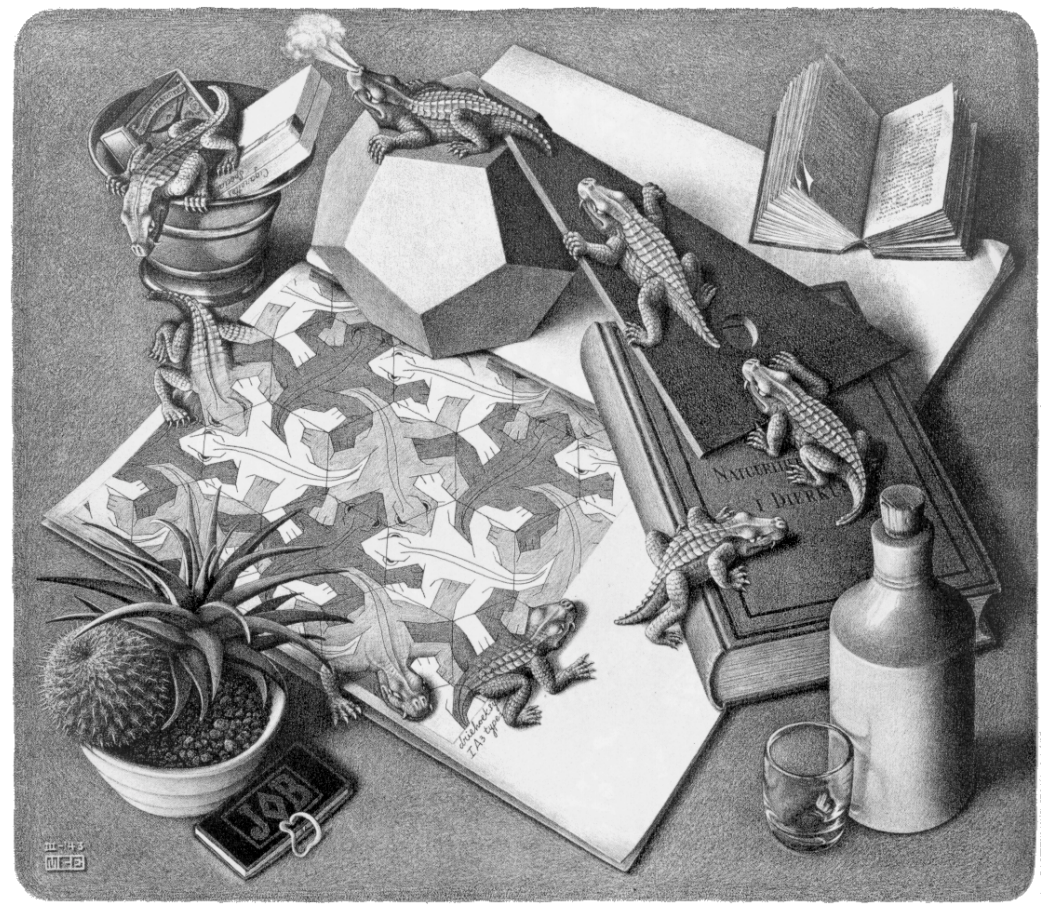

Figure 1. Reptiles. 1943.

...one single theme can appear on different levels of reality. For instance, one level in a drawing might clearly be recognizable as representing fantasy or imagination, another level would be recognizable as reality. These two levels might be the only explicitly portrayed levels. But the mere presence of these two levels invites the viewer to look upon himself as part of yet another level; and by taking that step, the viewer cannot help getting caught up in Escher's implied chain of levels, in which, for any level, there is always a level below, "more"imaginary" than it is (Hofstadter 1980: 15).

The Russellian-Gödelian analogy was applied to Nabokov's prose for the first time by Dr. Dinkin in his comments to "Ultima Thule" (January 19, 1949), a proto-text of "Bend Sinister", a fragment of the unfinished novel "Solus Rex", where the knowledge of death and afterlife is considered as a logical paradox: "Not long ago I read a similar thought in Bertrand Russell (History of Western Philosophy): if a philosophical system is perfectly logical, without any errors or contradic- 
tions, and thus well-balanced and absolutely closed in itself, it inevitably comes to incongruous results, is monstrous and loses any contact with "reality" " (Letters, folder 42; the translation is mine. -M. G.). "Ultima Thule" is a poem in a language unknown to the narrator. The narrator, a painter Sineusov, sets to illustrate the poem: the illustration is a parallel to his "narratological" task, an attempt to understand the mad Falter's "unspeakable" message. The latter, as a result of a certain "playful" combination of thoughts, is self-evident, logically inexplicable and unprovable. All endeavours to prove the existence of afterlife or to answer the question whether the word "heterological" is itself heterological (Nabokov 1990: 461) would end in a vicious circle. There is nevertheless a mysterious correlation between the world and the otherworld, a kind of cross-reference. D. B. Johnson has noticed the reverberation of the words of the narrator's dying wife in the madman's speech (Johnson 1985: 208), which is apparently to confirm the mysterious interdependence of the worlds. The auctorial point of view could be reconstructed as the result of the interdependence and located at the metametalevel where "the riddle of the universe" is to be solved.

In "Bend Sinister" the story is also conveyed in different languages or different versions of reality (the finite, closed and therefore "monstrous" totalitarian language; science languages; the idiosyncratical language of protagonist's thoughts and recollections; more and more incomplete and indefinite dream languages, etc.). Put through the various realities and evolving towards infinity, the story finally withdraws back into the author-persona. The author is the "otherworld" observer of the textual imaginary physical space: he is identical with the "consciousness" of the text. But, being also involved into the text from the inside and "embodied" in it, he becomes together with it a part of the outside physical reality. So the quest for infinity ends in a "strange loop", a finite representation of infinity: it "occurs whenever, by moving upwards (or downwards) through the levels of some hierarchical system, we unexpectedly find ourselves right back where we started" (Hofstadter 1980: 10, 15). The fictional space of "Bend Sinister" is unfolding as a chain of levels to be finally reversed into the paradoxical self-reference.

I am deeply grateful to Pekka Tammi for his valuable comments, to Mikhail Iampolskii and Richard Sieburth for the professional support, to Irina Shevelenko and Olga Skonechnaya for their assistance. I want to thank Diana Burnham and Stephen Crook who helped my work in 
the New York Public Library Berg Collection. I thank also the Open Estonia Foundation for the scholarship that made this work possible.

\section{References}

Barthes, Roland 1981. Camera Lucida. New York.

Boyd, Brian 1992. V. Nabokov. The American Years. London: Chatto \& Windus.

Damish, Hubert 1987. L'Origine de la Perspective. Paris: Flammarion.

[Dar. English]. The Gift. Chapters 2-5. Typescript draft of the novel, translated by M. Scammell with V. N. ms. corrections. - The NYPL Berg Collection Nabokov Archive.

Dolinin, Aleksandr 1999. Clio laughs last: Nabokov's answer to historicism. In: Connolly, J. W. (ed.), Nabokov and His Fiction. Cambridge: Cambridge University Press.

Dunne, John William 1934. The Serial Universe. London.

- 1973. An Experiment with Time. London.

Emerson, Ralph Waldo 1912. Journals of Ralph Waldo Emerson. 1841-44. Boston, vol. 6: 100-101.

Grishakova, Marina 1999. On Some Allusions in V. Nabokov's Works. The Nabokovian, no 43 (fall): 18-29.

Grossmith, Robert 1991. Shaking the Kaleidoscope: Physics and Metaphysics in Nabokov's Bend Sinister. Russian Literature Triquarterly 24: 151-162.

Hofstadter, Douglas R. 1980. Gödel, Escher, Bach: an Eternal Golden Braid. New York: Vintage Books.

Iser, Wolfgang 1993. The Fictive and the Imaginary. Charting Literary Anthropology. Baltimore and London: The Johns Hopkins University Press.

Johnson, Donald Barton 1985. Worlds in Regression: Some Novels of Vladimir Nabokov. Ardis: Ann Arbor.

Landau, Grigorii 1923. Sumerki Evropy. Berlin.

Letters to and from miscellaneous correspondents, 1925-1976. The NY Public Library Berg Collection Nabokov Archive.

Letters to G. P. Putnam's sons. The NY Public Library Berg Collection Nabokov Archive.

Levin, Jurij 1998. Bispacialnost' kak invariant poeticheskogo mira Vl. Nabokova. Izbrannye trudy. Poetika. Semiotika. Moskva: Iazyki russkoi kultury.

Leving, Jurij 1999. Literaturnyi podtekst palestinskogo pis'ma Vl. Nabokova. Novyi Zhurnal, 214.

Nabokov, Vladimir 1970. Ada or Ardor: A Family Chronicle. New York, A Fawcett Crest Book.

- 1972. Transparent Things. New York: McGraw-Hill.

- 1974. Bend Sinister. London: Penguin Books. 
- 1990. Ultima Thule. Sobranie sochinenii v 4 tomah. T. 4. Moskva: Pravda.

- 1991. Selected Letters 1940-77. Edited by D. Nabokov and M. J. Bruccoli. London: Vintage.

- 1995. The Real Life of Sebastian Knight. London: Penguin Books.

- 1997. Pnin. London: Penguin Books.

- 1999. Conclusive Evidence [The Unpublished Chapter]. The New Yorker, December, pp. 124-133.

Pascal, Blaise 1958. Pensées. Translated by W. F. Trotter. New York: E. P. Dutton \& Co., Inc.

Ravdin, Boris 1994. Vozvrashajas' k napechtannomu. Daugava 1.

Rorty, Richard 1989. Contingency, Irony, and Solidarity. Cambridge: Cambridge University Press.

Tammi, Pekka 1985. Problems of Nabokov's Poetics. A Narratological Analysis. Suomalainen Tiedeakatemia toimituksia, ser. B, tom 231. Helsinki.

- 1999. Russian Subtexts in Nabokov's Fiction. Tampere: Tampere University Press.

\section{“Bend Sinister" Владимира Набокова: социальное сообщение или эксперимент со временем?}

В статье анализируется "странный" роман В. Набокова "Bend Sinister". Художественное пространство романа рассматривается как процесс взаимодействия разных языков или разных версий реальности. История философа Круга развертывается в воображаемом тоталитарном государстве, идеология которого сочетает в себе элементы фашизма, коммунизма и языка массовой психологии. На этом уровне текст представляет собой "социальное сообщение". Герой стоит перед необходимостью выбора между личной автономией и "плохой солидарностью". Статья вводит новые факты и документы, образующие социальный подтекст романа. Язык "реальности" деконструируется в идиосинкразическом языке героя, языке его мыслей, воспоминаний и снов. Болышую роль в этой деконструкции играет научная метафора, которая выявляет метахудожественную природу текста: аналогии с живописью, релятивистской физикой, парадоксами логики (теории Рассела и Геделя) являются способами исследования статуса художественного пространства, развертывания текста во времени, фикции Автора. 


\title{
V. Nabokovi "Bend Sinister": sotsiaalne teade või eksperiment ajaga?
}

\begin{abstract}
Arrtiklis analüüsitakse Vladimir Nabokovi "kummalist" romaani "Bend Sinister". Romaani kunstilist ruumi vaadeldakse kui erinevate keelte (või erinevate reaalsuse versioonide) vastastikuste mõjutuste protsessi. Filosoof Krugi lugu hargneb kujuteldavas totalitaarriigis, mille ideoloogia ühendab endas kommunismi, fašismi ja massipsühholoogia keele elemente. Sellel tasandil kujutab tekst endast "sotsiaalset teadet". Kangelane seisab valiku ees - kas isiklik autonoomia või "halb solidaarsus". Kirjeldatakse uusi fakte ja dokumente, mis moodustavad romaani sotsiaalse allteksti. "Reaalsuse" keel dekonstrueeritakse peategelase mõtete, mälestuste ja unenägude idiosünkraatilises keeles. Olulist osa mängib selles dekonstruktsiooniprotsessis teaduslik metafoor, mis toob välja antud teksti metakunstilise olemuse: analoogiad maalikunstiga, relatiivse füüsikaga, loogika paradoksidega (Russelli ja Gödeli teooriad) on kunstilise ruumi staatuse, teksti ajas kulgemise ja Autori fiktsiooni uurimise moodusteks.
\end{abstract}

